\title{
Leucine Regulates the Exocrine Function in Pancreatic Tissue of Dairy Goats In Vitro
}

\author{
Yangchun Cao $\mathbb{D}^{\mathrm{D}},{ }^{1}$ Kai Liu, ${ }^{1}$ Shimin Liu, ${ }^{2}$ Long Guo, ${ }^{1}$ Junhu Yao $\mathbb{D}^{1},{ }^{1}$ and Chuanjiang Cai ${ }^{1}$ \\ ${ }^{1}$ College of Animal Science and Technology, Northwest A\&F University, Yangling 712100, China \\ ${ }^{2}$ UWA School of Agriculture and Environment, The University of Western Australia, Crawley, WA 6009, Australia
}

Correspondence should be addressed to Junhu Yao; yaojunhu2004@sohu.com and Chuanjiang Cai; sdcaicj@163.com

Received 21 June 2019; Revised 23 August 2019; Accepted 14 September 2019; Published 13 October 2019

Academic Editor: Ruxana Sadikot

Copyright ( 92019 Yangchun Cao et al. This is an open access article distributed under the Creative Commons Attribution License, which permits unrestricted use, distribution, and reproduction in any medium, provided the original work is properly cited.

This study aimed to investigate the effects of leucine (Leu) on the synthesis and secretion of digestive enzymes in cultured pancreatic tissue of dairy goats and on the signaling molecules. Fresh pancreatic tissue from dairy goats was cut into approximately $2 \mathrm{~mm} \times 2 \mathrm{~mm}$ pieces and incubated in oxygenated Krebs-Ringer bicarbonate buffer containing 0 (the control), 0.40, 0.80, or $1.60 \mathrm{mM}$ Leu at $39^{\circ} \mathrm{C}$ in a $\mathrm{CO}_{2}$ incubator for $180 \mathrm{~min}$. The results showed that Leu increased the release of $\alpha$-amylase, trypsin, and chymotrypsin in the buffer and tissue, as well as the total activity $(P<0.05)$, especially at 0.40 and $0.80 \mathrm{mM}$. Compared with the control, $1.60 \mathrm{mM}$ Leu increased the release of $\alpha$-amylase and the total activity of trypsin and chymotrypsin $(P<0.05)$ but had no effect on the tissue concentration of $\alpha$-amylase, trypsin, and chymotrypsin or the total activity of $\alpha$-amylase $(P>0.05)$. Leu improved the mRNA expression of $\alpha$-amylase, trypsin, and chymotrypsin $(P<0.05)$, especially at 0.80 and $1.60 \mathrm{mM}$. The activity and mRNA expression of lipase were not affected $(P>0.05)$. Compared with the control, 0.40 and $0.80 \mathrm{mM}$ Leu increased the expression of the $\gamma$ isoform of 4EBP1 $(P<0.05)$, implying increased phosphorylation of 4EBP1. Leu increased the phosphorylation of S6K1 $(P<0.05)$. Compared with the control, 0.40 and $0.80 \mathrm{mM}$ Leu decreased the eEF2 phosphorylation level $(P<0.05)$. Conclusively, these results suggested that Leu could regulate the synthesis of pancreatic enzymes by increasing the mRNA expression and phosphorylation level of protein factors in the mammalian target of rapamycin pathway and the optimal Leu level in this experiment was $0.80 \mathrm{mM}$.

\section{Introduction}

The synthesis of proteins is completed by mRNA translation, which consists of initiation, elongation, and termination. The synthesis rate depends on the amount of mRNA and the intracellular ribosomes, as well as their translation efficiency [1]. The translation efficiency is dependent on the initiation and elongation of translation, which is regulated by eukaryotic initiation and elongation factors [2].

Mammalian target of rapamycin (mTOR) is a kinase, which serves as a core catalytic component of mTOR complex 1 (mTORC1) and mTOR complex 2; the mTOR pathway plays a very important role in the translation initiation and is the central regulator of metabolism of animal bodies $[3,4]$. As a highly conserved protein, mTOR can sense cellular nutrient, oxygen, and energy levels [5]. It has been shown that the phosphorylation status of its upstream and downstream target protein molecules in the mTOR pathway can be regulated by amino acids, leading to stimulation of the protein synthesis [6]. Compared with nonessential amino acids, essential amino acids $(3.5 \mathrm{mmol} / \mathrm{l})$ increased mTOR phosphorylation by $100 \%$, and the depletion of leucine (Leu) or isoleucine (Ile) alone could result in a decrease in mTOR phosphorylation by $57 \%$ or $47 \%$, respectively $[7,8]$. In addition, signal transmission by mTORC1 could be strongly inhibited by a lack of energy or amino acids, and a supply of amino acids to starving cells could significantly increase the activity of mTORC1 [9]. However, the molecular mechanism of regulation of the mTOR pathway by amino acids is still unclear.

Therefore, we hypothesized that Leu, as a functional amino acid, could change the phosphorylation status of the 
mTOR signal pathway, which could result in an increase in enzyme synthesis and excretion in the pancreas. To test this hypothesis, we focused on the main signal factors, including eukaryotic initiation factor $4 \mathrm{E}$ binding protein 1 (4EBP1), ribosomal protein S6 kinase 1 (S6K1), and eukaryotic elongation factor 2 (eEF2). The main goals of this study were to investigate the effects of Leu on the mTOR signal pathway and to define the associations between these signalling activities and the synthesis of pancreatic enzymes using an in vitro model of cultured pancreatic tissue of dairy goats.

\section{Materials and Methods}

All procedures used in this experiment complied with the animal care protocol that was approved by the Northwest A\&F University Animal Care and Use Committee.

2.1. Pancreatic Tissue Preparation. Three one-year-old healthy Guanzhong dairy goats were used for taking pancreatic tissue. The three goats were slaughtered one goat per day over three days to provide fresh pancreatic tissues for the cultures.

When the goats were slaughtered, the caudal portion of the pancreas was removed immediately. The techniques described are based on similar procedures used for other species or purposes [10-16]. Briefly, mesentery, fat, and lymph were removed from the pancreas. Approximately $10 \mathrm{~g}$ of pancreas tissue from each goat was quickly excised once the goat was dead, placed in ice-cooled saline $(0.9 \% \mathrm{NaCl})$, and immediately sent to the laboratory.

2.2. Tissue Isolation and Incubation. The incubation techniques described were based on the same procedures used in our previous study [17]. The pancreas piece was transferred to ice-cold Krebs-Ringer bicarbonate for tissues isolation and incubation. A separate aliquot of tissue was homogenised in saline and stored at $-30^{\circ} \mathrm{C}$ until analysis of $\alpha$-amylase, trypsin, and lipase activity.

2.3. Treatments and Experimental Design. There were four Leu treatments with medium containing $0,0.40,0.80$, and $1.60 \mathrm{mM}$ Leu. Dulbecco's modified Eagle's medium (DMEM)/Ham' F12 (HyClone, Logan, UT, USA) was used as the basal culture medium. The working Leu concentrations in the medium were $0.40,0.80$, and $1.60 \mathrm{mM} \mathrm{Leu,} \mathrm{and}$ the control medium $(0 \mathrm{mM})$ was the same as the treatment medium but contained no Leu (special custom medium; HyClone). After incubation for 180 mins, the tissues were harvested by scraping in the presence of ice-cold lysis buffer containing $1 \%(\mathrm{v}: \mathrm{v})$ protease and phosphatase inhibitor cocktails (Roche, China). The culture medium was also collected for further analysis of enzymes activity. Culturing of the tissues was repeated for 3 days. On each day, tissues from a goat were cultured in four culture flasks, each containing one of the four kinds of media. Therefore, each Leu treatment had a total of three replicates from three goats $(n=3)$.

\subsection{Sample Analysis}

2.4.1. In Vitro Enzyme Release. To measure the activity of digestive enzymes in the tissue segments, we collected the supernatant of the homogenate after homogenising. The activities of $\alpha$-amylase, trypsin, and lipase in the supernatant of the homogenate and culture medium were determined using commercial kits (Nanjing Jiancheng Bioengineering Institute, China). One unit of enzyme activity was defined as $1 \mu \mathrm{mol}$ of product released per minute at $39^{\circ} \mathrm{C}$.

\subsubsection{Quantification of Amylase, Trypsin, and Lipase $m R N A$} Levels. RNA was isolated from the pancreas samples according to the method described by previous studies $[17,18]$. The total RNA concentration was quantified by measuring its absorbance at $260 \mathrm{~nm}$ using a NanoDrop 2000 spectrophotometer (Thermo Scientific Inc. Wilmington, DE, USA). The sample integrity was determined from the ratio of absorbance at $260 \mathrm{~nm}$ to $280 \mathrm{~nm}$, which was equal to or greater than 2.0 in all samples [19]. Reverse transcription (RT) of the mRNA was performed using a PrimeScript ${ }^{\circledR}$ RT Reagent Kit (TaKaRa Biotechnology Co., Ltd., Dalian, China). Primers used for the PCR are listed in Table 1. The mRNA levels of various tissues were assessed using the $2^{-\Delta \Delta \mathrm{Ct}}$ method [20], and $\beta$-actin was used as the internal housekeeping gene control [21].

2.4.3. Protein Immunoblot Analysis. Immunoblot analysis of $4 \mathrm{EBP} 1, \mathrm{~S} 6 \mathrm{~K} 1$, and eEF2 protein was performed according to the method described by previous studies [17, 22]. A ChemiDOC XRS + imaging system (Bio-Rad, Germany) was used to visualise the target protein bands using an enhanced chemiluminescence reaction (ECL Kit, Bio-Rad, Cat. 1705061, CA, USA). Western blots were developed and quantified using Image J software (Windows version, National Institution of Health). When performing SDS-PAGE, the 4EBP1, S6K1, and eEF2 bands were separated into three subtypes, and the highly phosphorylated subtype $(\gamma$-subtype) moved the slowest. The proportion of $\gamma$-subtype relative to the total 4EBP1, S6K1 and eEF2 protein was calculated to indicate the extent of 4EBP1, S6K1, and eEF2 phosphorylation, respectively. The primary antibodies used were rabbit anti-goat polyclonal serum antibodies (4EBP1 from Calbiochem, Germany; S6K1 and eEF2 from Abcam, $\mathrm{UK})$, and the secondary antibodies were goat anti-rabbit horseradish peroxidase conjugates (Beijing Synthetic Technology Co., Ltd., China).

2.5. Statistics. Analyses of enzyme activities, mRNA expression, and 4EBP1, S6K1, and eEF2 phosphorylation content were performed using the GLM procedure for a oneway analysis of variance (ANOVA) model in SAS software. Protein expression content was calculated relative to that of $\beta$-actin based on the band intensities. Differences with $P<0.05$ were considered significant, and the data are presented as the mean \pm standard error of the mean (SEM). 
TABle 1: Primer sequences.

\begin{tabular}{|c|c|c|c|c|}
\hline Target genes & Reference sequence & Primer sequence $\left(5^{\prime}-3^{\prime}\right)$ & Product size (bp) & Annealing temperature $\left({ }^{\circ} \mathrm{C}\right)$ \\
\hline Amylase & NM_001035016 & $\begin{array}{l}\text { F: GAAATGGCCGTGTGACAGAATTTA } \\
\text { R: ACAAAGACAAGTGCCCTGTCAGAA }\end{array}$ & 142 & 64.3 \\
\hline Trypsin & NM_001113727 & $\begin{array}{c}\text { F: TGTCTGCGGCTCACTGCTAC } \\
\text { R: GCTGGGATGGACGATACTCTTG }\end{array}$ & 119 & 62.7 \\
\hline Chymotrypsin & NM_001098965.1 & $\begin{array}{l}\text { F: ATGTTGGGCATCACGGTCTT } \\
\text { R: TGTGCCTCCACGTGTTATCC }\end{array}$ & 172 & 60.0 \\
\hline Lipase & NM_001205820 & $\begin{array}{l}\text { F: GTGGAAGCAAATGATGGACAAG } \\
\text { R: TGGGTTGAGGGTGAGCAGA }\end{array}$ & 81 & 61.8 \\
\hline$\beta$-Actin & AF481159 & $\begin{array}{l}\text { F: ACCACTGGCATTGTCATGGACTCT } \\
\text { R: TCCTTGATGTCACGGACGATTTCC }\end{array}$ & 152 & 60.0 \\
\hline
\end{tabular}

\section{Results}

As shown in Table 2, Leu increased the release of $\alpha$-amylase, trypsin, and chymotrypsin into the buffer and tissue, as well as their total activities $(P<0.05)$, especially at concentrations of 0.40 and $0.80 \mathrm{mM}$. Compared with the control, $1.60 \mathrm{mM}$ Leu increased the release of $\alpha$-amylase and the total activity of trypsin and chymotrypsin $(P<0.05)$ but not the tissue concentrations of $\alpha$-amylase, trypsin, and chymotrypsin or the total activity of $\alpha$-amylase $(P>0.05)$. The activity of lipase was unaffected $(P>0.05)$.

As shown in Figure 1, Leu increased the mRNA expression of $\alpha$-amylase, trypsin, and chymotrypsin $(P<0.05)$, especially at concentrations of 0.80 and $1.60 \mathrm{mM}$. The mRNA expression of lipase was unaffected $(P>0.05)$.

Compared with the control, 0.40 and $0.80 \mathrm{mM}$ Leu increased the expression of the $\gamma$ isoform of 4EBP1 (Figure 2(a), $P<0.05$ ), which means that the phosphorylation of 4EBP1 was increased. Leu increased the phosphorylation of S6K1 (Figure 2(b), $P<0.05$ ). Compared with the control, 0.40 and $0.80 \mathrm{mM}$ Leu decreased the eEF2 phosphorylation level (Figure 2(c), $P<0.05$ ).

\section{Discussion}

The method of tissue incubation in vitro evaluating the regulation of pancreatic exocrine function in response to nutrients has rarely been studied, especially in ruminants, and there have only been three papers elaborating on this method in dairy cows $[16,17,23]$. This study improved on the in vitro tissue incubation method based on previous studies [10-16]. The key to successfully incubate tissues is to shorten the time involved in sampling and preprocessing of tissues, as well as the incubation conditions. A RS Biotech as a cell culture chamber rather than flasks filled with $95 \% \mathrm{O}_{2}$ and $5 \% \mathrm{CO}_{2}$ [16], as well as a thermostat concussion water bath tank, were used in this experiment, which ensured the accuracy of the experiment.

Three measurements of the activities of the enzymes were performed in this experiment: tissue concentration, release into the buffer, and total activity (the sum of the tissue concentration and release). The total activity indicates the synthesis of enzymes by the pancreas tissue, and the release of enzymes indicates the amount of enzyme that could be active for nutrient digestion. Leu increased the
TABLe 2: Effects of leucine on the activities of enzymes in vitro.

\begin{tabular}{|c|c|c|c|c|c|c|}
\hline \multirow{2}{*}{ Item } & \multicolumn{4}{|c|}{ Levels of leucine $(\mathrm{mM})^{1}$} & \multirow{2}{*}{$\mathrm{SEM}^{2}$} & \multirow{2}{*}{$P$} \\
\hline & 0 & 0.40 & 0.80 & 1.60 & & \\
\hline \multicolumn{7}{|c|}{ Tissue concentration (U/g) } \\
\hline$\alpha$-Amylase & $572^{\mathrm{b}}$ & $681^{\mathrm{a}}$ & $658^{\mathrm{a}}$ & $581^{\mathrm{b}}$ & 48.5 & 0.017 \\
\hline Trypsin & $3.45^{\mathrm{c}}$ & $5.69^{\mathrm{b}}$ & $7.67^{\mathrm{a}}$ & $3.88^{\mathrm{c}}$ & .573 & $<0.001$ \\
\hline Chy & $2.68^{\mathrm{b}}$ & $4.31^{\mathrm{a}}$ & $4.86^{\mathrm{a}}$ & $3.11^{\mathrm{b}}$ & 0.736 & 0.008 \\
\hline Lipa & 402 & 197 & & 525 & & 258 \\
\hline \multicolumn{7}{|c|}{ Release (U/g tissue) } \\
\hline$\alpha$-Amylase & $221^{c}$ & $308^{\mathrm{a}}$ & 310 & $268^{\mathrm{b}}$ & 37.6 & 0.012 \\
\hline Tryl & $1.05^{\mathrm{b}}$ & $2.57^{\mathrm{a}}$ & $2.48^{\mathrm{a}}$ & $2.71^{\mathrm{a}}$ & 0.474 & 0.029 \\
\hline Chy & $0.88^{\mathrm{b}}$ & $2.30^{\mathrm{ab}}$ & $2.61^{\mathrm{a}}$ & $2.77^{\mathrm{a}}$ & 0.385 & 0.024 \\
\hline Lipase & 116 & 112 & & 121 & 1 & 0.207 \\
\hline \multicolumn{7}{|c|}{ Total activity (U/g tissue) } \\
\hline$\alpha$-Amylase & $793^{\mathrm{b}}$ & $989^{\mathrm{a}}$ & $968^{\mathrm{a}}$ & $849^{\mathrm{b}}$ & 75.145 & $<0.001$ \\
\hline Trypsil & $4.50^{c}$ & $8.26^{\mathrm{ab}}$ & $10.15^{\mathrm{a}}$ & $6.59^{\mathrm{b}}$ & 0.652 & 0.005 \\
\hline Chyn & $3.36^{\mathrm{c}}$ & $6.61^{\mathrm{ab}}$ & $7.47^{\mathrm{a}}$ & $5.88^{\mathrm{b}}$ & 0.536 & 0.012 \\
\hline Lipase & 518 & 607 & 655 & 646 & 20.7 & 0.092 \\
\hline
\end{tabular}

${ }^{1}$ One-way ANOVA. Differences were considered significant at $P<0.05$.

${ }^{2}$ Pooled standard error of the means, $n=3,{ }^{a-c}$ Means within a row not sharing the same superscript differ significantly $(P<0.05)$.

tissue concentration, release, and total activity of $\alpha$-amylase, especially at 0.40 and $0.80 \mathrm{mM}$, while no effect on the activity of $\alpha$-amylase was found at $1.60 \mathrm{mM}$ compared with the control. A previous in vivo study in our laboratory showed that the concentration $(\mathrm{U} / \mathrm{ml})$ and the secretion rate $(\mathrm{U} / \mathrm{h})$ could be increased at most by $45.0 \%$ and $54.5 \%$, respectively [24]. However, the total activity of $\alpha$-amylase was increased by $24.7 \%$ at most in the present study, which is lower than the effect observed in animals [24]. A reason for this could be ascribed to the multiple factors that affect the activity of $\alpha$-amylase in animals but not in vitro, such as nutrients, neuroregulation, and hormonal regulation $[25,26]$. The release of $\alpha$-amylase was increased by Leu, and the effects at 0.40 and $0.80 \mathrm{mM}$ were better than those at $1.60 \mathrm{mM}$, in contrast to the results found by previous study [16]. Different physiological stages and treatments in the different experiments could be the reason for different results, since calves were infused with Leu [16].

The activities of trypsin and chymotrypsin were increased by Leu. The total activity of trypsin and chymotrypsin could be increased by $225.6 \%$ and $222.3 \%$, respectively, which were much higher levels than those in a previous study on heifers [24]. When the in vitro tissue incubation method is used, most of the other factors that 


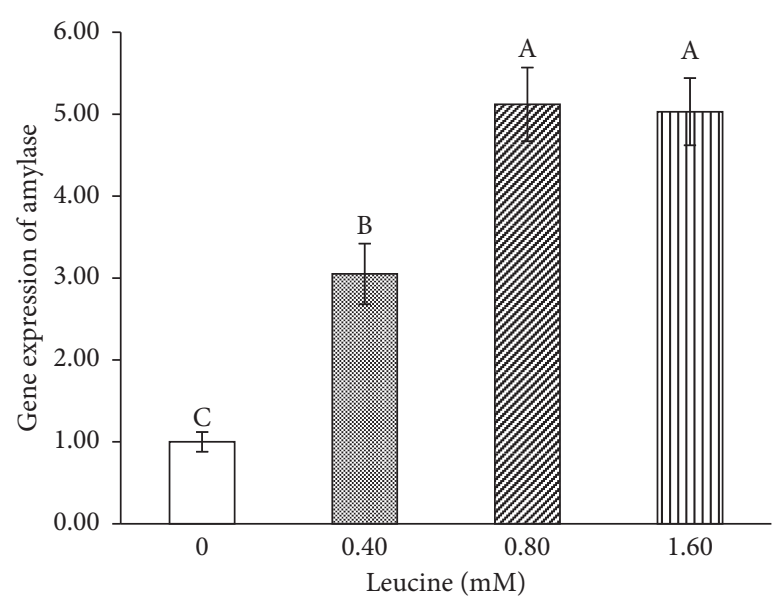

(a)

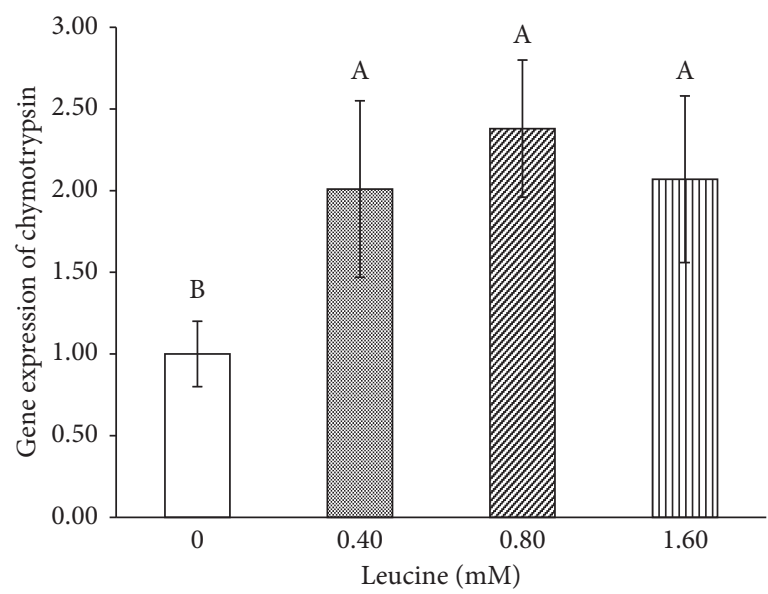

(c)

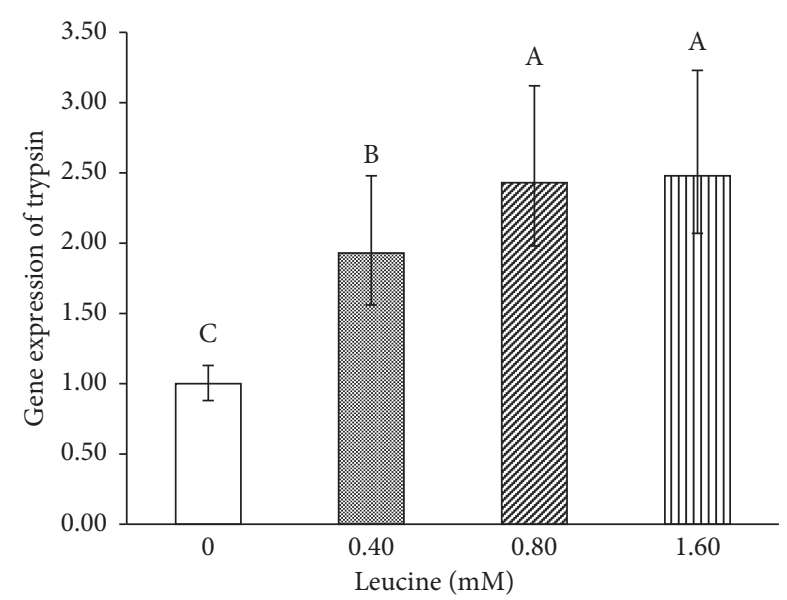

(b)

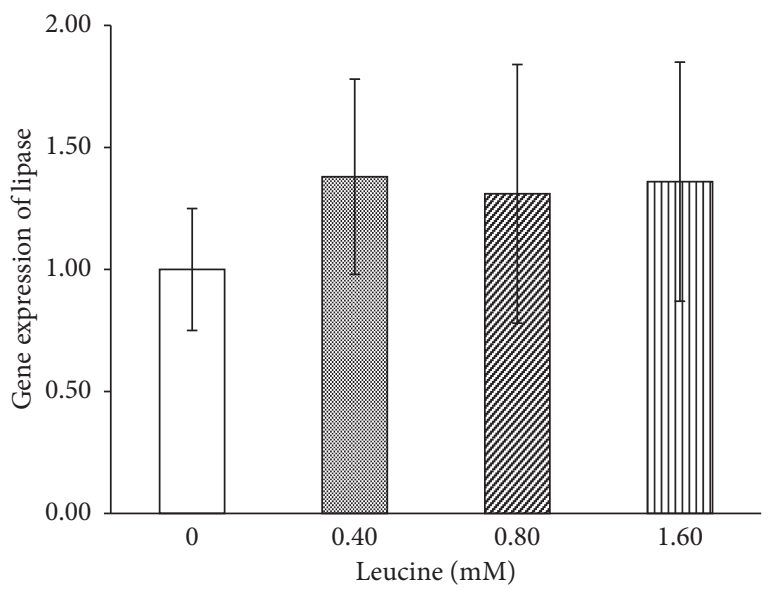

(d)

FIGURE 1: Effects of leucine on pancreatic amylase (a), trypsin (b), chymotrypsin (c), and lipase (d) mRNA levels in vitro. Values are the mean and pooled standard error of the mean (SEM). The enzyme mRNA levels were normalized to those of $\beta$-actin mRNA, and values of the mRNA levels were compared with those of the control group as 1.00. Different letters represent significantly different values $(P<0.05, n=3)$.

could affect the synthesis of enzymes are excluded and Leu remains as the only main factor regulating pancreatic exocrine function; therefore, its effects on the synthesis of enzymes should be much more distinct.

Leu could improve the synthesis and secretion of pancreatic enzymes by regulating the expression of various mRNAs. The mRNA expression of $\alpha$-amylase, trypsin, and chymotrypsin was increased by Leu, especially at high levels. It has been shown that Leu could regulate the transcription and translation of islet cells and other cells through the mTOR pathway and other pathways [27-30]. The activity of pancreatic $\alpha$-amylase decreased with increasing starch flow in the duodenum, while protein administration could increase the secretion of $\alpha$-amylase [16]. A previous study in dairy goats by our group showed that a high level $(9 \mathrm{~g} / \mathrm{d})$ but not a low level $(3 \mathrm{~g} / \mathrm{d})$ of Leu increased the mRNA expression of $\alpha$-amylase, while no effects on the activities of trypsin and lipase were observed [31]. At $1.60 \mathrm{mM}$, Leu increased the mRNA expression of $\alpha$-amylase, trypsin, and chymotrypsin but not the tissue concentrations of these enzymes.

Cells could change their gene expression profiles in response to different environments. Although proteins are the products of new mRNAs in response to the transcription stage, cells could also regulate gene expression by regulating translation [32-35]. Thus, as a preprocessing stage of protein translation, mRNA translation into proteins is largely but not crucially regulated by nutrients. The reason that high-level Leu $(1.60 \mathrm{mM})$ could increase mRNA expression but not enzyme secretion could be related to the protein translation efficiency.

Previous studies have shown that branched-chain amino acids could regulate the protein synthesis of islet $\beta$-cells by activating the mTOR pathway $[28,29,36,37]$. It has been verified that $0.4-4.0 \mathrm{mM}$ Leu could increase the phosphorylation level of p70S6K in islet $\beta$-cells which increases protein synthesis, and this process is sensitive to rapamycin but not insulin [28, 37, 38]. A study using the mammary epithelial cells of cows showed that the deprivation of all amino acids or Leu alone could decrease the phosphorylation of 4EBP1 and S6K1 in the mTOR pathway [39]. In addition, the administration of Leu alone could increase the phosphorylation level of mTOR as well as the synthesis rate of protein fragments $[7,8]$.

In our experiment, Leu could increase the phosphorylation level of $4 \mathrm{EBP} 1$ and S6K1 and decrease the 


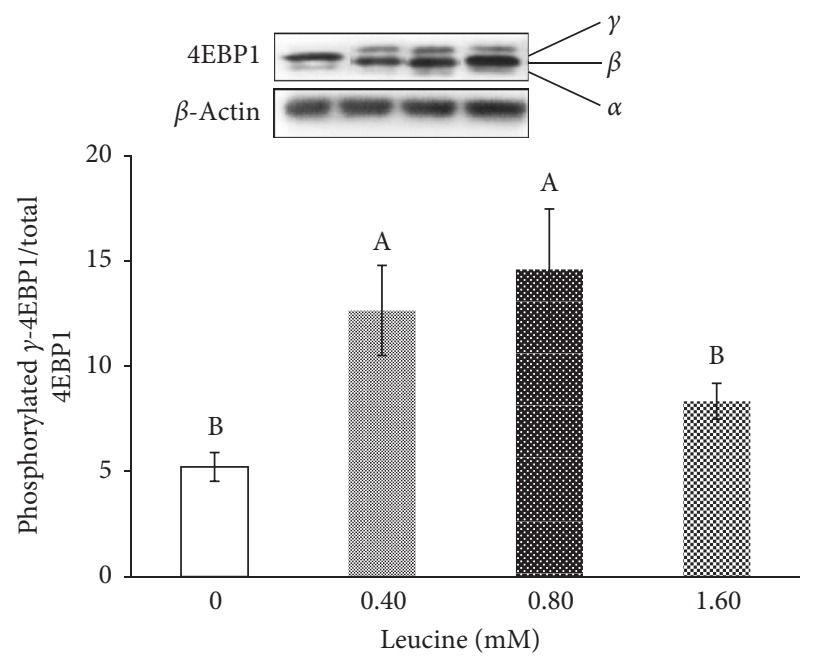

(a)

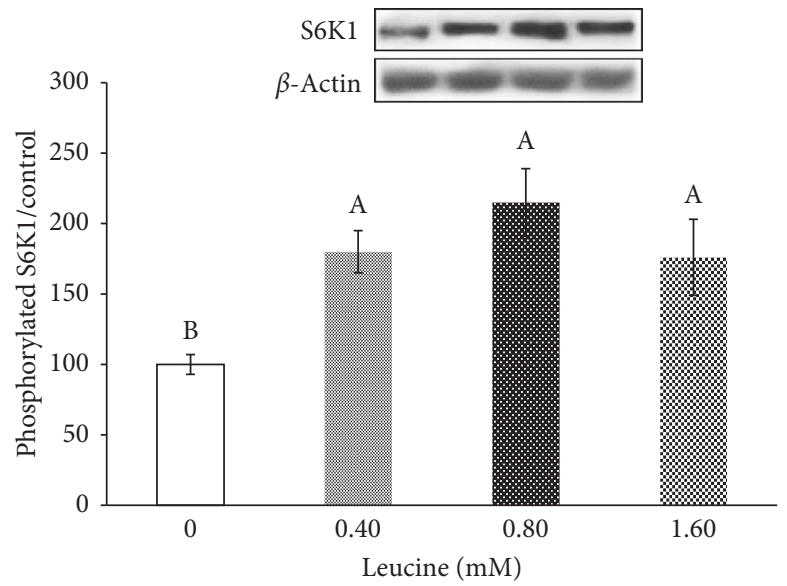

(b)

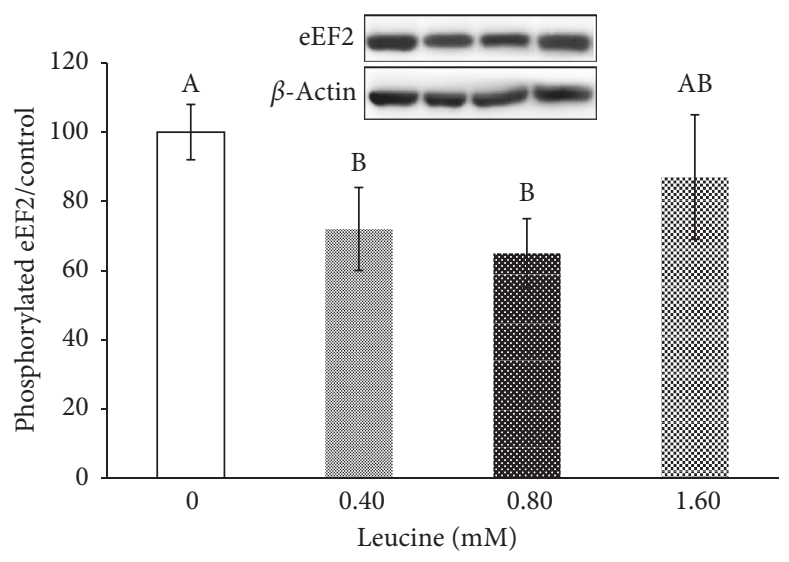

(c)

FIGURE 2: Effects of leucine on the ratio of phosphorylated to total mTOR signalling pathway factors in pancreas tissue. (a) 4 EBP1 ( $\alpha$, $\beta$, and $\gamma$ forms are denoted); (b) S6K1; (c) eEF2. The data are the means and pooled standard errors of the means (SEM). Different letters represent significantly different values $(P<0.05, n=3)$.

phosphorylation of eEF2, which is in accordance with a previous study by our team [31]. In terms of the effects of Leu on eEF2, previous studies have shown that the activity of eEF2 increased linearly with the levels of essential amino acids but not with Leu alone [7, 8]. The reason for this finding could be related to the different experimental methods. A cell starvation method was used in the experiment in which antagonistic amino acids were applied that weakened or counteracted the effects of Leu on eEF2 [8]. In addition, the regulation of protein factors in the translation process increased first and then decreased with a peak at $0.80 \mathrm{mM}$ Leu, which is consistent with the results by Apelo et al. [40].

\section{Conclusion}

In conclusion, Leu could regulate the synthesis of pancreatic enzymes by increasing the mRNA expression and the phosphorylation level of protein factors in the mTOR pathway, and the optimal level of Leu in this experiment was $0.80 \mathrm{mM}$.

\section{Data Availability}

The data used to support the findings of this study are available from the corresponding author upon request.

\section{Conflicts of Interest}

The authors declare that they have no conflicts of interest.

\section{Acknowledgments}

This work was supported by the National Key Research and Development Program of China (nos. 2018YFD0501600 and 2017YFD0500500) and the Science \& Technological Project of Ningxia Autonomous Region, China (no. 2018BBF33007).

\section{References}

[1] T. G. Anthony, J. C. Anthony, F. Yoshizawa, S. R. Kimball, and L. S. Jefferson, "Oral administration of leucine stimulates ribosomal protein mRNA translation but not global rates of 
protein synthesis in the liver of rats," The Journal of Nutrition, vol. 131, no. 4, pp. 1171-1176, 2001.

[2] D. Chu, E. Kazana, N. Bellanger, T. Singh, M. F. Tuite, and T. von der Haar, "Translation elongation can control translation initiation on eukaryotic mRNAs," The EMBO Journal, vol. 33, no. 1, pp. 21-34, 2014.

[3] S. S. Schalm and J. Blenis, "Identification of a conserved motif required for mTOR signaling," Current Biology, vol. 12, no. 8, pp. 632-639, 2002.

[4] S. S. Schalm, D. C. Fingar, D. M. Sabatini, and J. Blenis, "TOS motif-mediated raptor binding regulates $4 \mathrm{E}-\mathrm{BP} 1$ multisite phosphorylation and function," Current Biology, vol. 13, no. 10, pp. 797-806, 2003.

[5] C. Tokunaga, K.-i. Yoshino, and K. Yonezawa, "mTOR integrates amino acid- and energy-sensing pathways," Biochemical and Biophysical Research Communications, vol. 313, no. 2, pp. 443-446, 2004.

[6] S. A. Burgos, M. Dai, and J. P. Cant, "Nutrient availability and lactogenic hormones regulate mammary protein synthesis through the mammalian target of rapamycin signaling pathway," Journal of Dairy Science, vol. 93, no. 1, pp. 71537161, 2010.

[7] J. A. D. R. N. Appuhamy, A. L. Bell, W. A. D. Nayananjalie, J. Escobar, and M. D. Hanigan, "Essential amino acids regulate both initiation and elongation of mRNA translation independent of insulin in MAC-T cells and bovine mammary tissue slices," The Journal of Nutrition, vol. 141, no. 6, pp. 1209-1215, 2011.

[8] J. A. D. R. N. Appuhamy, N. A. Knoebel, W. A. D. Nayananjalie, J. Escobar, and M. D. Hanigan, "Isoleucine and leucine independently regulate mTOR signaling and protein synthesis in MAC-T cells and bovine mammary tissue slices," The Journal of Nutrition, vol. 142, no. 3, pp. 484-491, 2012.

[9] E. Jacinto and M. N. Hall, "Tor signalling in bugs, brain and brawn," Nature Reviews Molecular Cell Biology, vol. 4, no. 2, pp. 117-126, 2003.

[10] J. A. Williams and M. Lee, "Pancreatic acinar cells: Use of a $\mathrm{Ca}++$ ionophore to separate enzyme release from the earlier steps in stimulus-secretion coupling," Biochemical and Biophysical Research Communications, vol. 60, no. 2, pp. 542548, 1974.

[11] J. A. Williams, "An in vitro evaluation of possible cholinergic and adrenergic receptors affecting pancreatic amylase secretion," Experimental Biology and Medicine, vol. 150, no. 2, pp. 513-516, 1975.

[12] J. Williams and D. Chandler, "Ca++ and pancreatic amylase release," American Journal of Physiology-Legacy Content, vol. 228, no. 6, pp. 1729-1732, 1975.

[13] D. D. Carson, B. J. Earles, and W. J. Lennarz, "Enhancement of protein glycosylation in tissue slices by dolichylphosphate," Journal of Biological Chemistry, vol. 256, no. 22, pp. 1155211557, 1981.

[14] K. Katoh and T. Tsuda, "Effects of acetylcholine and shortchain fatty acids on acinar cells of the exocrine pancreas in sheep," The Journal of Physiology, vol. 356, no. 1, pp. 479-489, 1984 .

[15] K. Katoh and T. Yajima, "Effects of butyric acid and analogues on amylase release from pancreatic segments of sheep and goats," Pflügers Archiv-European Journal of Physiology, vol. 413, no. 3, pp. 256-260, 1989.

[16] K. C. Swanson, J. C. Matthews, C. A. Woods, and D. L. Harmon, "Postruminal administration of partially hydrolyzed starch and casein influences pancreatic $\alpha$-amylase expression in calves," The Journal of Nutrition, vol. 132, no. 3 , pp. 376-381, 2002.

[17] Y. C. Cao, K. Liu, S. M. Liu, L. Guo, C. Cai, and J. Yao, "Isoleucine regulates the synthesis of pancreatic enzymes via the activation of mRNA expression and phosphorylation in the mammalian target of rapamycin signalling pathways in pancreatic tissues," BioMed Research International, vol. 2019, Article ID 6302950, 7 pages, 2019.

[18] D. C. Wathes, Z. Cheng, W. Chowdhury et al., "Negative energy balance alters global gene expression and immune responses in the uterus of postpartum dairy cows," Physiological Genomics, vol. 39, no. 1, pp. 1-13, 2009.

[19] Y. Zhu, Y. Guan, J. J. Loor et al., "Fatty acid-induced endoplasmic reticulum stress promoted lipid accumulation in calf hepatocytes, and endoplasmic reticulum stress existed in the liver of severe fatty liver cows," Journal of Dairy Science, vol. 102, no. 8, p. 12, 2019.

[20] K. J. Livak and T. D. Schmittgen, "Analysis of relative gene expression data using real-time quantitative PCR and the $2^{-\Delta \Delta \mathrm{Ct}}$ method," Methods, vol. 25, no. 4, pp. 402-408, 2001.

[21] I. M. Frota, C. C. Leitao, J. J. Costa et al., "Effects of BMP-7 and FSH on the development of goat preantral follicles and levels of mRNA for FSH-R, BMP-7 and BMP receptors after in-vitro culture," Animal Reproduction, vol. 8, no. 1/2, pp. 25-31, 2011.

[22] S. J. Crozier, M. D. Sans, C. H. Lang, L. G. D’Alecy, S. A. Ernst, and J. A. Williams, "CCK-induced pancreatic growth is not limited by mitogenic capacity in mice," American Journal of Physiology-Gastrointestinal and Liver Physiology, vol. 294, no. 5, pp. G1148-G1157, 2008.

[23] L. Guo, H. Tian, J. Shen et al., "Phenylalanine regulates initiation of digestive enzyme mRNA translation in pancreatic acinar cells and tissue segments in dairy calves," Bioscience Reports, vol. 38, no. 1, 2018.

[24] K. Liu, Y. Liu, S. M. Liu et al., "Relationships between leucine and the pancreatic exocrine function for improving starch digestibility in ruminants," Journal of Dairy Science, vol. 98, no. 4, pp. 2576-2582, 2015.

[25] D. L. Harmon, R. M. Yamka, and N. A. Elam, "Factors affecting intestinal starch digestion in ruminants: a review," Canadian Journal of Animal Science, vol. 84, no. 3, pp. 309318, 2004.

[26] D. L. Harmon, "Understanding starch utilization in the small intestine of cattle," Asian-Australasian Journal of Animal Sciences, vol. 22, no. 7, pp. 915-922, 2009.

[27] E. Blomstrand, J. Eliasson, H. K. R. Karlsson, and R. Köhnke, "Branched-chain amino acids activate key enzymes in protein synthesis after physical exercise," The Journal of Nutrition, vol. 136, no. 1, pp. 269S-273S, 2006.

[28] G. Kwon, C. A. Marshall, K. L. Pappan, M. S. Remedi, and M. L. McDaniel, "Signaling elements involved in the metabolic regulation of mTOR by nutrients, incretins, and growth factors in islets," Diabetes, vol. 53, no. 3, pp. S225-S232, 2004.

[29] M. H. Stipanuk, "Leucine and protein synthesis: mTOR and beyond," Nutrition Reviews, vol. 65, no. 3, pp. 122-129, 2007.

[30] F. Yoshizawa, "Regulation of protein synthesis by branchedchain amino acids in vivo," Biochemical and Biophysical Research Communications, vol. 313, no. 2, pp. 417-422, 2004.

[31] Z. P. Yu, M. Xu, F. Wang et al., "Effect of duodenal infusion of leucine and phenylalanine on intestinal enzyme activities and starch digestibility in goats," Livestock Science, vol. 162, pp. 134-140, 2014.

[32] C. H. de Moor and J. D. Richter, "Translational control in vertebrate development," International Review of Cytology, vol. 203, pp. 567-608, 2001. 
[33] E. Klann and T. E. Dever, "Biochemical mechanisms for translational regulation in synaptic plasticity," Nature Reviews Neuroscience, vol. 5, no. 12, pp. 931-942, 2004.

[34] M. Holcik and N. Sonenberg, "Translational control in stress and apoptosis," Nature Reviews Molecular Cell Biology, vol. 6, no. 4, pp. 318-327, 2005.

[35] M. A. Sutton and E. M. Schuman, "Local translational control in dendrites and its role in long-term synaptic plasticity," Journal of Neurobiology, vol. 64, no. 1, pp. 116-131, 2005.

[36] M. L. McDaniel, C. A. Marshall, K. L. Pappan, and G. Kwon, "Metabolic and autocrine regulation of the mammalian target of rapamycin by pancreatic-cells," Diabetes, vol. 51, no. 10, pp. 2877-2885, 2002.

[37] G. Xu, G. Kwon, W. S. Cruz, C. A. Marshall, and M. L. McDaniel, "Metabolic regulation by leucine of translation initiation through the mTOR-signaling pathway by pancreatic-cells," Diabetes, vol. 50, no. 2, pp. 353-360, 2001.

[38] G. Xu, G. Kwon, C. A. Marshall, T.-A. Lin, J. C. Lawrence, and M. L. McDaniel, "Branched-chain amino acids are essential in the regulation of PHAS-I and p70 S6 kinase by pancreatic $\beta$-cells: a possible role in protein translation and mitogenic signaling," Journal of Biological Chemistry, vol. 273, no. 43, pp. 28178-28184, 1998.

[39] Y. Moshel, R. E. Rhoads, and I. Barash, "Role of amino acids in translational mechanisms governing milk protein synthesis in murine and ruminant mammary epithelial cells," Journal of Cellular Biochemistry, vol. 98, no. 3, pp. 685-700, 2006.

[40] S. I. A. Apelo, L. M. Singer, X. Y. Lin, M. L. McGilliard, N. R. St-Pierre, and M. D. Hanigan, "Isoleucine, leucine, methionine, and threonine effects on mammalian target of rapamycin signaling in mammary tissue," Journal of Dairy Science, vol. 97, no. 2, pp. 1047-1056, 2014. 


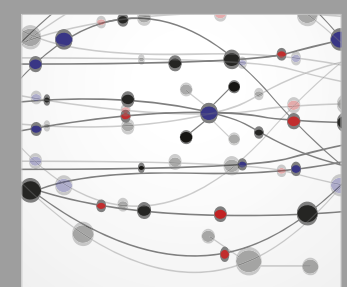

The Scientific World Journal
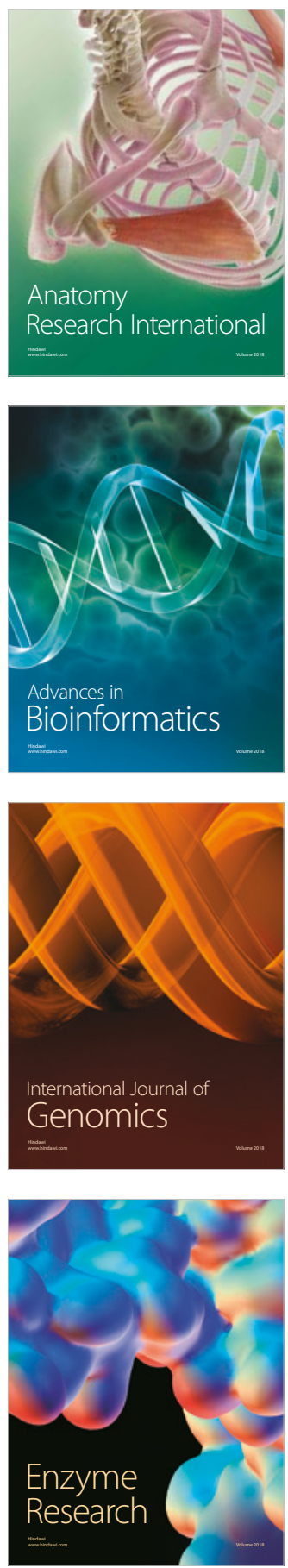
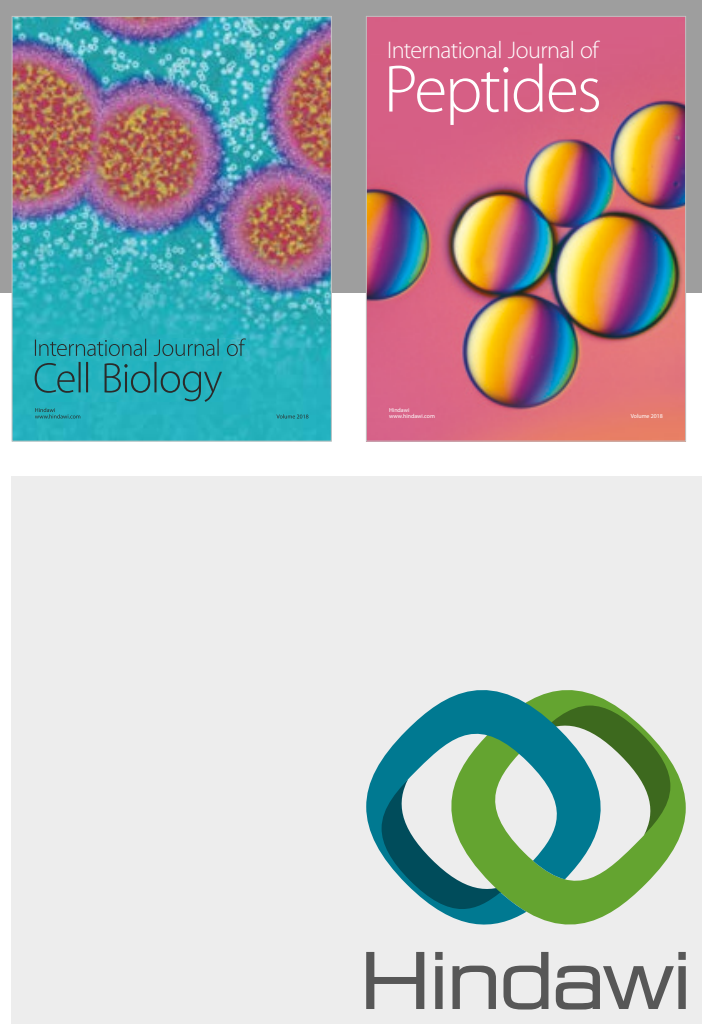

Submit your manuscripts at

www.hindawi.com
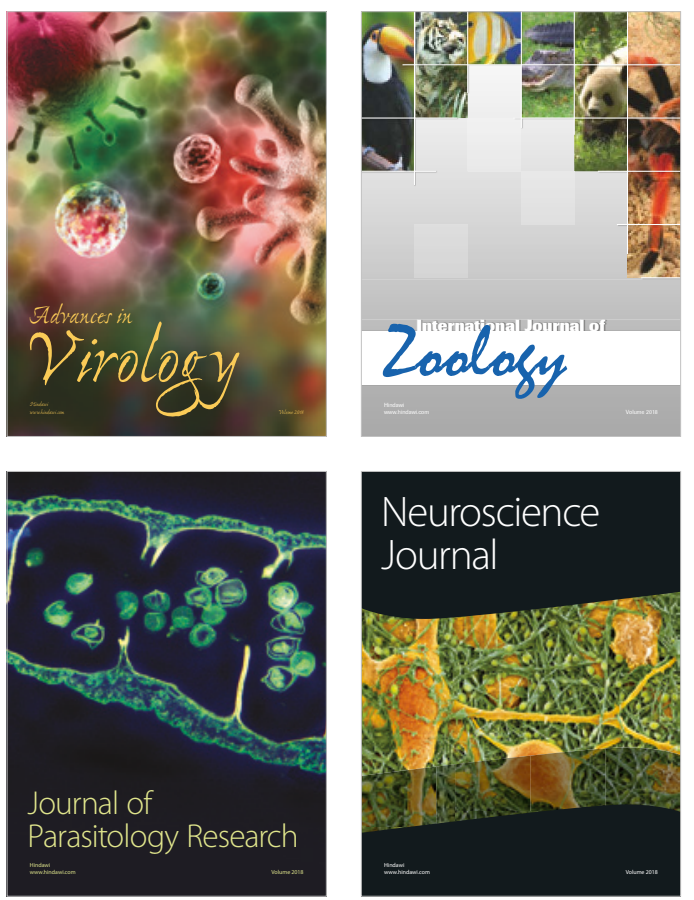
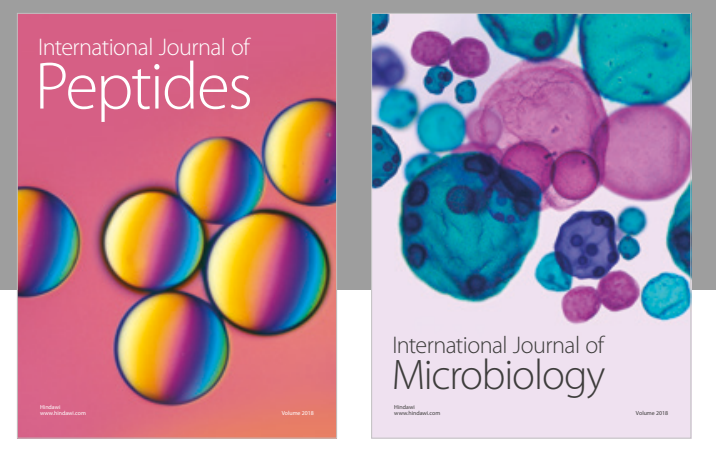

nternational Journal of Microbiology
Journal of
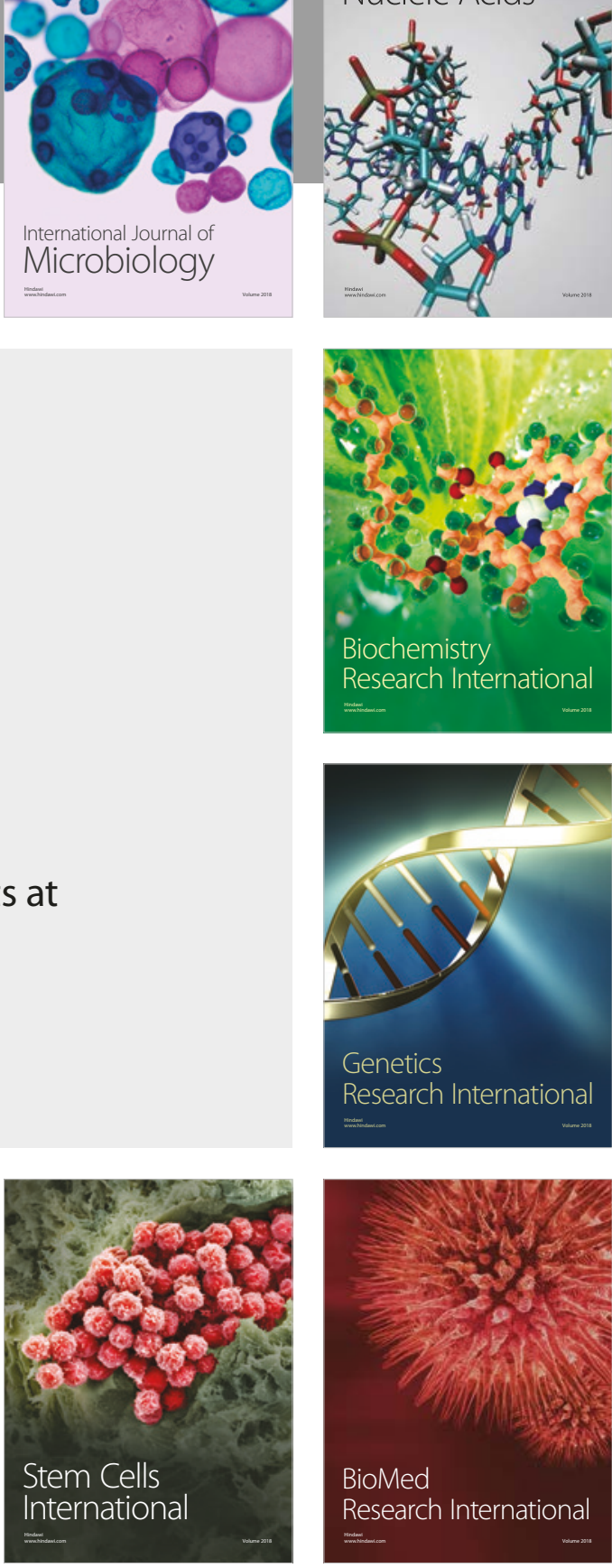
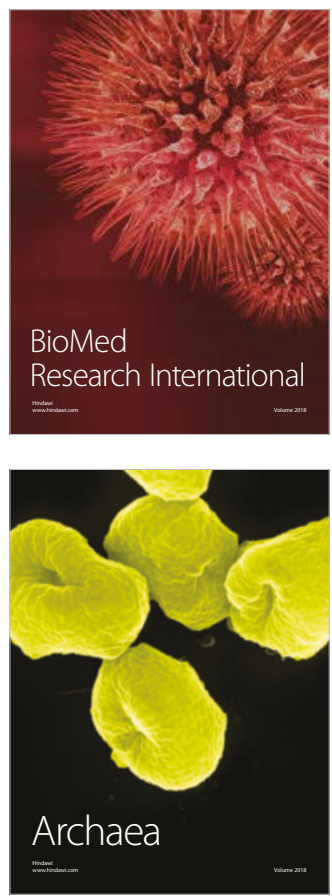